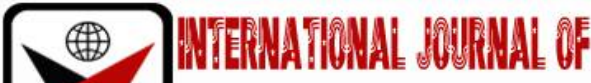

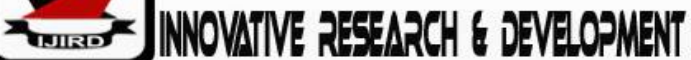

ISSN 2278 - 0211 (Online)

\section{Consequences of Malaria on Buruku Local Government Area of Benue State's Rural Households' Farm Income: A Nigeria Based Study}

Ogebe, F. O
Senior Lecturer, Department of Agricultural Economics, Federal University of Agriculture,
Makurdi, Benue State, Nigeria
Burbwa, P.A
Assistant Lecturer, Department of Agricultural Economics,
Federal University of Agriculture, Nigeria

\begin{abstract}
Malaria is one of the most occurring diseases in African continent especially in rural areas of Africa. It creates serious hazards for rural households'. This study focuses on the impact of malaria on productivity and income of rural households along with preventive measures taken by the Government with focus of Buruku Local Government Area of Benue State, Nigeria. With a sample size of 200, data have been collected through a structured questionnaire. The result of regression revealed that majority (80.0\%) of the farmers in the study area were male, married (49.0\%) with one form of formal educational attainment or the other. Majority (85.0\%) of the farmers were within the productive age group with average age of 46 years and mean household size of 11 persons. The mean farm size was 3.0 hectares and average annual farm income of $\$ 228,022.50$. Majority (47.5\%) of the households are affected with malaria between 3-4 times in a year with an average number of 4 persons in a household and about 26 days of incapacitation. Surveyed households mostly used bed nets as protective measures against malaria attack which is believed to be best preventive measure as well as cheap and affordable. This study also suggested some of the steps to handle this situation like intensification of the "Roll Back Malaria Campaign", use of mosquito nets etc.
\end{abstract}

Keywords: Malaria, households, effects, incapacitation, Nigeria

\section{Introduction}

Malaria is a health problem that results from mosquito bites, the parasite being mainly Plasmodium falciparum. The disease remains one of the most serious health problems in the world and is a major public health problem in Nigeria (Narain, 2008). It accounts for about $60 \%$ of all out- patients' attendance and $30 \%$ of all hospital admission in Nigeria (FMH, 2007).According to MIM (2001), between 700,000 and 2.7 million death occur because of malaria. Malaria has been mentioned not only a health problem but also an economic problem as it costs for Africa more than 12 billion US dollars annually. As per Coluzzi (2010), along with government, households have to spend a lot to control mosquitoes in two segments expenditure on prevention and expenditure on treatment. Asenso-Okyere and Dzarto (1997) had mentioned many expenditures like drugs consumption, laboratory tests, transport fees in order to cope from it. For Mills (1998), between $\$ 2$ and $\$ 25$ is the amount for treatment of malaria and between $\$ 15$ and $\$ 20$ on prevention each month.

This study focuses on the following areas

- Illustrate the socio-economic character of the respondents;

- Estimation of the frequency of malaria on farming households;

- Assess the effect of malaria on agricultural productivity;

- Estimate the value of labor forgone by infected malaria households; and

- Estimate households' expenditure on malaria illness.

\section{Theoretical Framework}

Malaria is seriously causing problem like anguish even death for countries south of Sahara consisting largest population in Nigeria. It effects drastically in availability and productivity of labors in many areas like land area put under production, untimely farm operations, food security etc. (Asenso-Okyere et al., 2009). De Leire and Manning (2004) also found the consequences of malaria in the same zones of productivity. In a word it can be said that supply of labor, decisions on how many hours of labor to supply suffers due to this (Alabaand Alaba, 2009). As healthy human capital always has proved to be more productive compare to less health human capital, malaria is becoming more serious as it interferes with health, in turn productivity (Alves et al. ,2003). Many studies like Asenso-Okyere et al. (2009), mentioned 
many areas where human is suffering due to malaria like reduction area under cultivation, plating of less labor-intensive crops, changes in cropping patterns, adoption of labor scarce innovations. Findings of Malaney (2003) are also in the same line. Ochi et al. (2007), also highlighted damaging effect of malaria by mentioning that over 90 percent of farming population in Nigeria, commonly faces serious consequences like death because of malaria.

\section{Method and Empirical Model}

The study area is the Buruku Local Government Area of Benue State, Nigeria. Buruku has a land area of $1,246 \mathrm{~km}^{2}$ and a total population of 206,215 people (National Bureau of Statistics [NBS], 2016). The geographical coordinates are longitudes 7047 and $10^{\circ} 0 \mathrm{E}$, and latitudes $6^{\circ} 25$ and $8^{0} 8 \mathrm{~N}$ with average annual temperature of $27^{\circ} \mathrm{C}$ and annual rainfall of $900-1000 \mathrm{~mm}$. Firming is the primary occupation whereas, hunting, trading, artisan, civil service jobs are the secondary occupations. Yam, cassava, rice and other Nigerian staples are the majorly produced staples. Sampling technique is the simple random sampling technique. The entire government had been divided into five wards based on the geographical location and two (2) villages were selected from each ward. A random selection has been made for twenty (20) farming households from each village which finally makes 200 respondents. Data had been collected through structured questionnaire focusing on the socio-economic characteristics and on malaria incidence as it affects rural households' health and their agricultural labor productivity. Analysis has been done using both descriptive and inferential statistics.

\subsection{Model Specification}

\subsubsection{Effects of Malaria Illness on Crop Production}

The model specifies productivity (proxy farm income) of the respondents as dependent variable (Y). That is:

$\mathrm{Y}_{\mathrm{A}}=\mathrm{f}\left(\mathrm{X}_{1}, \mathrm{X}_{2}, \mathrm{X}_{3}, \mathrm{X}_{4}, \mathrm{X}_{5}, \mathrm{X}_{6}, \mathrm{Y}_{\mathrm{T}}\right)$....

$\mathrm{Y}_{\mathrm{A}}=$ Total annual income of respondents in Naira

$\mathrm{X}_{1}=$ Age in years

$\mathrm{X}_{2}=$ Household size (number)

$\mathrm{X}_{3}=$ Farm size (hectares)

$\mathrm{X}_{4}=$ Total days of incapacitation

$\mathrm{X}_{5}=$ Food expenditure in Naira

$\mathrm{X}_{6}=$ Non-food expenditure in Naira

$\mathrm{X} 7=$ Frequency of malaria illness

$\mathrm{X} 8=$ Distance to the source of malaria treatment

$X 9=$ Cost of treatment in Naira

$\mathrm{Y}_{\mathrm{T}}=$ Total income lost due to malaria illness in Naira

$\mathrm{e}=$ error term

\subsection{Economic Lost Approach}

The monetary value of the production, as a function (f) of days of incapacitation was computed using the Economic Loss formula.

*US\$1-equivalent=f $\left(\mathrm{F}_{\mathrm{t}} \cdot \mathrm{A}_{\mathrm{t}}\right)$

Where, Ft = average number of days of farm time lost due to malaria illness, $A_{t}=$ average labor wage/ man-day (in US\$equivalent). For the purpose of estimating the economic value of the average days of incapacitation (ADI), two benchmarks, namely; national daily minimum wage (NDMW), and average (Benue State) daily labor wage (BDLW) rate were established. The NDMW of \$591.78 (or \$1.64) in Nigeria was based on the 2011 approved national monthly minimum wage of $\$ 18,000$ (or $\$ 49.72$ ) per capita, and BDLW ( $\$ 800$ or $\$ 2.21$ ) per capita is the current daily labor wage rate in Benue State. However, the daily labor wage rate can be different in time and space across the state depending on the demand and supply of labor. (*US\$1=N362)

\section{Results and Discussion}

\subsection{Socio-Economic Characteristics of Respondents}

Table 1 indicates that 46 years is the average age of farmers with 11 as mean household size. The average annual farm income was $\$ 228,022.50$ (equivalent to $\$ 19,001.875$ per month), while the average days of incapacitation from farm work was 26days in a year. This implies that that majority (85\%) of the farmers still are within productive active age group. This study also finds that as household size increase food security also increases. The same findings reflected through the studies of Jiang and Braun, 2005; Ogebe, Umeh\& Abu, 2017, Russell, 2004. The area under study indicates that a mean firm size of 3.0 is enough for consumption and productions. The low average monthly farm income of $\# 19,001.875$ indicates very poor earning situation of the farmers indicating an earning of $\$ 633.40$ per day which is below the poverty line of $\$ 3.00$ per day at $\$ 365$ per Dollar (CBN, 2018) 


\begin{tabular}{|c|c|c|}
\hline Variables & Frequency & Percentage \\
\hline \multicolumn{3}{|l|}{ Sex } \\
\hline Male & 160 & 80 \\
\hline Female & 40 & 20 \\
\hline \multicolumn{3}{|l|}{ Age (years) } \\
\hline $15-25$ & 30 & 15 \\
\hline $26-35$ & 40 & 20 \\
\hline $36-45$ & 60 & 30 \\
\hline $46-55$ & 40 & 20 \\
\hline $56-65$ & 20 & 10 \\
\hline $66-75$ & 10 & 5 \\
\hline 60 and above & 0 & 0 \\
\hline Average & 46 & \\
\hline \multicolumn{3}{|l|}{ Marital Status } \\
\hline Single & 42 & 21 \\
\hline Married & 98 & 49 \\
\hline Widow & 15 & 7.5 \\
\hline Others & 45 & 22.5 \\
\hline \multicolumn{3}{|l|}{ Educational level (years) } \\
\hline No education & 42 & 21 \\
\hline Primary/Adult education & 48 & 24 \\
\hline Secondary education & 80 & 40 \\
\hline Higher/Tertiary education & 30 & 15 \\
\hline \multicolumn{3}{|l|}{ Household size } \\
\hline $1-5$ & 21 & 10.5 \\
\hline $6-10$ & 97 & 48.5 \\
\hline $11-15$ & 71 & 35.5 \\
\hline $16-20$ & 10 & 5 \\
\hline$>20$ & 1 & 0.5 \\
\hline Average & 11 & \\
\hline \multicolumn{3}{|l|}{ Farm size (ha) } \\
\hline $0.5-1.5$ & 70 & 35 \\
\hline $2.0-3.0$ & 55 & 27.5 \\
\hline $3.5-4.5$ & 50 & 25 \\
\hline $5.0-6.0$ & 20 & 10 \\
\hline $6.5-7.0$ & 5 & 2.5 \\
\hline Average & 2.8 & \\
\hline \multicolumn{3}{|l|}{ Farming experience (years) } \\
\hline 01-Oct & 40 & 20 \\
\hline Nov-20 & 45 & 22.5 \\
\hline $21-30$ & 80 & 40 \\
\hline $31-40$ & 35 & 17.5 \\
\hline \multicolumn{3}{|l|}{ Annual Farm income ( $\mathrm{N}$ ) } \\
\hline $1,000-100,000$ & 58 & 29 \\
\hline $101,000-200,000$ & 72 & 36 \\
\hline $201,000-300,000$ & 28 & 14 \\
\hline $301,000-400,000$ & 16 & 8 \\
\hline $401,000-500,000$ & 14 & 7 \\
\hline $501,000-600,000$ & 8 & 4 \\
\hline $601,000-700,000$ & 4 & 2 \\
\hline Average & $228,022.50$ & \\
\hline
\end{tabular}

Table 1: Socio-economic Characteristics of Respondents Source: Survey Data, 2019

\subsection{Incidence of Malaria on Farming Households}

Table 2 indicates that most of the like $70 \%$ of the respondents have faced malaria attack having 4 as average household size. Awoniyi et al. (2012), also found in line with this by founding $70 \%$ of household with malaria attack in Ekiti and Niger States of Nigeria. Dirty environment, residents are being found as reason behind this. Generally, malaria found to be caused between 3-4 times in a year as reported by most households (47.5\%) with average days of incapacitation of 26 days. This causes heavy on productivity as hired labor can never substitute perfect labor (Chima et al., 2003). 92.5\% of household adopts orthodox medication as way of treatment. Whereas, about $33.0 \%$ of the households still depend on self-medication due to inaccessibility to medical healthcare centers for effective treatment of malaria. Bed nets are found to be widely used preventive methods due to low cost. 


\begin{tabular}{|c|c|c|}
\hline Variables & Frequency & Percentage \\
\hline \multicolumn{3}{|l|}{ No. of people Affected } \\
\hline 01-Mar & 60 & 30 \\
\hline 04-Jun & 80 & 40 \\
\hline 07-Sep & 40 & 20 \\
\hline 10-Dec & 20 & 10 \\
\hline Mean & 4 & \\
\hline \multicolumn{3}{|l|}{ Times Affected in a Year } \\
\hline $01-\mathrm{Feb}$ & 55 & 27.5 \\
\hline 03-Apr & 95 & 47.5 \\
\hline 05-Jun & 37 & 18.5 \\
\hline 07-Aug & 13 & 6.5 \\
\hline Mean & 2.65 & \\
\hline \multicolumn{3}{|l|}{ Days of Incapacitation/year } \\
\hline Jan-15 & 10 & 5 \\
\hline $16-20$ & 82 & 41 \\
\hline $21-25$ & 80 & 40 \\
\hline $26-30$ & 26 & 13 \\
\hline $31-35$ & 2 & 1 \\
\hline $\begin{array}{c}\text { Mean } \\
\end{array}$ & 26 & \\
\hline \multicolumn{3}{|c|}{ Days of Work Missed by Caregivers } \\
\hline 01-Mar & 30 & 15 \\
\hline 04-Jun & 80 & 40 \\
\hline 07-Sep & 60 & 30 \\
\hline 10-Dec & 20 & 10 \\
\hline$>12$ & 10 & 5 \\
\hline Mean & 14 & \\
\hline \multicolumn{3}{|l|}{ Preventive Measures } \\
\hline Use of bed nets & 80 & 40 \\
\hline Use preventive drugs & 50 & 25 \\
\hline Use insecticides & 25 & 12.5 \\
\hline Use of door/window nets & 50 & 25 \\
\hline Retire early to bed & 40 & 20 \\
\hline Use mosquito coils & 60 & 30 \\
\hline \multicolumn{3}{|l|}{ Treatment Measures } \\
\hline Visit hospital & 88 & 44 \\
\hline Use malaria drugs & 97 & 48.5 \\
\hline Visit herbalists & 66 & 33 \\
\hline
\end{tabular}

Table 2: Incidence of Malaria on Farming Households ( $n=200$ )

Source: Survey data, 2019

\subsection{Effects of Malaria on Agricultural Productivity}

The result of regression (Table 4) shows $\mathrm{R}^{2}$ of 0.79 . This clearly indicates that $79 \%$ of the change in the dependent variable can be explained by the explanatory variable which represents a good fit for the model. Farm size $\left(\mathrm{X}_{3}\right)$, food expenditure $\left(\mathrm{X}_{5}\right)$, non-food expenditure $\left(\mathrm{X}_{6}\right)$ and total income lost to malaria $\left(\mathrm{Y}_{\mathrm{T}}\right)$ are statistically significant at $(\mathrm{P}<0.01)$ while household size $\left(\mathrm{X}_{2}\right)$ is statistically significant at $(\mathrm{P}<0.05)$. However, age $\left(\mathrm{X}_{1}\right)$ and days of incapacitation $\left(\mathrm{X}_{4}\right)$ are not statistically significant at in amplification the variation in the annual income realized from the farm which is a proxy used to measure productivity of farmers.

As age is having negative coefficient which indicates that income decreases with increase in age as older farmers generally tends to have large household size, they are more prone to sickness.

The negative beta coefficient of the days of incapacitation $\left(\mathrm{X}_{4}\right)$ supported the theoretical expectation, that malaria illness would cause real crop output reduction. Also, farm size $\left(\mathrm{X}_{3}\right)$ has a positive beta coefficient indicating that annual income increases with increase in acreage of land cultivated. The positive beta coefficients of food $\left(\mathrm{X}_{5}\right)$ and non-food $\left(\mathrm{X}_{6}\right)$ expenditures show increase in expenditure as income of the farmers' increases. This is expected because the greater the income of the farmers, the more they tend to spend on food and non-food items. Crop output gets affected $(p<0.01)$ due to malaria illness among the farm households. Food security gets negatively affected due to malaria attack like Endah and Ndambi (2006). Even, crop production gets severely affected with travelling time and the fare paid to reach the treatment site-proxy for distance to sources with $95 \%$ confidence interval. The cost of treatment negatively affects household crop production with $95 \%$ confidence interval. Lastly, in some lost has positive coefficient which clearly implies that high income earning farmers tend to lose more of their income due to better treatment they seek which attracts high cost. 


\begin{tabular}{|c|c|c|c|c|}
\hline Variables & Coefficients & Std. error & T-statistics & Probability \\
\hline Constant & -9938.99 & 38042.62 & -0.261 & 0.795 \\
\hline Age $\left(\mathrm{X}_{1}\right)$ & -382.489 & 758.046 & 0.505 & 0.615 \\
\hline HHSize $\left(\mathrm{X}_{2}\right)$ & -2889.32 & 2040.126 & 1.416 & $0.026^{* *}$ \\
\hline Farm Size $\left(\mathrm{X}_{3}\right)$ & 21684.16 & 4095.305 & 5.295 & $0.000^{* * *}$ \\
\hline Days of Incap. $\left(\mathrm{X}_{4}\right)$ & -1919.01 & 3848.981 & -0.498 & 0.62 \\
\hline FoodExp $\left(\mathrm{X}_{5}\right)$ & 1.03 & 1.681 & 0.613 & $0.000^{* * *}$ \\
\hline NfoodExp $\left(\mathrm{X}_{6}\right)$ & 0.538 & 0.309 & 1.74 & $0.006^{* * *}$ \\
\hline Malaria fq $\left(\mathrm{X}_{7}\right)$ & -0.07542 & 0.01651 & -4.567 & $0.000^{* * *}$ \\
\hline Distance $\left(\mathrm{X}_{8}\right)$ & -36.2963 & 19.0799 & -1.904 & $0.056^{*}$ \\
\hline Cost of treatment $\left(\mathrm{X}_{9}\right)$ & -64.7361 & 28.6199 & -2.177 & $0.067^{*}$ \\
\hline Income lost $\left(\mathrm{Y}_{\mathrm{T}}\right)$ & 1.759 & 0.858 & 2.05 & $0.004^{* * *}$ \\
\hline R-Square $\left(\mathrm{R}^{2}\right)=0.790$ & & & & \\
\hline Adjusted $\mathrm{R}^{2}=0.794$ & & & & \\
\hline F-statistics & 30.16 & & & \\
\hline
\end{tabular}

Table 3: Linear Regression Functional Form Showing the Effect of Malaria Illness on Rural

Households' Farm Income

Source: Survey data, 2019

${ }^{* * *}(P<0.01),{ }^{* *}(P<0.05),{ }^{*}(0.1)$

\subsection{Estimated Value of Labor Forgone}

An average of 26 workdays was gone astray as a direct effect of malaria-specific illness during the cropping season, which also represented the actual wage and/ or revenue forgone by malaria infected households. The proxy for opportunity cost of labor was benchmarked in the Nigerian national minimum wage (NMW) and the Benue state average daily labor wage (BADW) RATE. Using the NMW and BADW, the average days of incapacitation of 26 days translated to $\$ 15,386.28$ (or $\$ 42.50$ ) and $\$ 20,800$ (or \$57.46) respectively. Analysis regarding incapacitation recognizes the methodological difficulties involved in the assessment of the opportunity cost of labor due to due to incapacitation as many elements of cost connected with opportunity cost of labor (as a result of illness or death) do not lend themselves for valuation in monetary terms.

\subsection{Households' Expenditure on Malaria Illness}

To find out the amount of money spend for prevention of malaria, households were asked to tell the amount as well to indicate how much they spend on food and non-food items for the month under consideration. Table 3 indicates that an average of $\$ 9,034.13$ representing 3.98\% of their annual farm income to prevent malaria attack in their households and used $\$ 10,006.13$ in treating the disease for each episode in a year. It has been found that on an average episode occurs 2.65 times on the average per year thus making the household to spend a total of $\$ 26,516.25$ to teat malaria per year which represents about $11.63 \%$ of their average annual farm income. Similar with the report of World Health Organization (WHO, 1999), this study found that the households incurred a total cost $\$ 35$, 600.38 in a year (preventive and treatment costs). Compared to the average annual farm income earned by famers from sales of their agricultural produce $(\$ 228,022.50)$, an average of $15.61 \%$ or $\$ 192,422.12$ of rural households' farm income is lost to malaria attack in the study area. Akazili (2002), also found that Northern Ghana found that the cost of malaria care was $34 \%$ of the income of poor households.

\begin{tabular}{|c|c|}
\hline Variable & Mean Amount ( $\mathrm{N}$ ) \\
\hline \multicolumn{2}{|l|}{ Cost of Malaria } \\
\hline (a) $\quad$ Preventive & $9,084.13$ \\
\hline Treatment cost per episode & $10,006.13$ \\
\hline No. of times Affected in a year & 2.65 \\
\hline (d) Total treatment Cost per year & $26,516.25$ \\
\hline Total Cost of Malaria/year & $35,600.38$ \\
\hline Average Farm Income & $228,022.50$ \\
\hline Income Lost to Malaria & $192,422.12$ \\
\hline Percentage Income Lost to Malaria & $15.61 \%$ \\
\hline \multicolumn{2}{|l|}{ Household Expenditure } \\
\hline (a) Expenditure on Food items & $10,832.75$ \\
\hline (b) $\quad$ Non-Food Expenditure & 73997.09 \\
\hline Total Welfare Cost & $84,828.84$ \\
\hline Percentage Income Used for Family Welfare & $37.20 \%$ \\
\hline
\end{tabular}

Table 4: Household Income Lost to Malaria in the Study Area Source: Survey Data, 2019 


\section{Conclusion and Recommendations}

For victims, malaria is causing both health and economic problem especially in rural households. Families with more dependents generally have lower income which pushes them into poverty belt. This in turn causes serious problems for malaria treatment as well as prevention. The result of this study clearly has indicated lower productivity as well as income of farmers. This study also suggested that "Roll Back Malaria Campaign", use of mosquito nets should be started with more seriously.

\section{References}

i. Akazili, J, (2002). Costs to households of seeking Malaria care in the Kassena-Nankana District of Northern Ghana. Third MIM Pan-African Conference on Malaria, Arusha, Tanzania, November 17-22. Bethesda, MD, Multilateral Imitative on Malaria: abstract 473.

ii. Alaba, O. A \&Alaba, O.B, (2009). Malaria in rural Nigeria: Implications for the Millennium Development Goals. African Development Review, 21 (7), 73-85

iii. Alves, L. F; M. V. Andrade \& P. B. R. Macedo, (2003). Health and Labor Market in Brazil. www.google.com

iv. Asenso-Okyere, K; F. A. Asante, J. Tarekegn\& K. S. Andam, (2009). The Linkage between Agriculture and Health. International Food Policy Research Institute. Discussion Paper No. 00861. Washington D.C: International Food Policy Research Institute.

v. Asenso-Okyere, K. \&Dzator, J.A, (1997). Household cost of seeking Malaria care: A retrospective study of two districts in Ghana. Social Science and Medicine 45(5): 659-667.

vi. Awoniyi, S.O.M., Amos, T.T \&Omole, M.M, (2010). "Rice famers' productivity in Nigeria: How has malaria not helped International Food Policy Research Institute? Discussion Paper, Washington DC, 2006-1007

vii. Central Bank of Nigeria [CBN], (2018). Dollar to Naira Exchange Rate. http//www.cbn.gov.ng/rates/exchratebyCurrency.asp

viii. Chima, R. T; C. A. Goodman \& A. Mills, (2003). The Economic Impact of Malaria in Africa: a critical review of the evidence. Health Policy, 63 (1) 17 - 36

ix. Coluzzi, M, (1999). "The Clay feet of the malaria giant and its African roots: hypotheses and inferences about origin, spread and control of Plasmodium falciparum". Parasitologia, 41: 277-283.

x. De leire, T \& W. Manning, (2004). "Labor Market Cost of Illness. Prevalence matter." Health Economics 13: 239 250

xi. Endah, N.B \&Ndambi, O.A, (2006). Impact of Malaria on Food Production in the Western Highlands of Cameroon. http://www.tropentag.de/2006/proceedings/node404.html.

xii. Federal Ministry of Health [FMH], (2007). National Framework for Monitoring and Evaluation of Malaria Control in Nigeria. FMOH, Abuja.

xiii. Jiang, Y.S \& Braun, J, (2005). The economic cost of illness and household coping strategies in Western rural China, Chinese Rural Economy, 11:3-39.

xiv. Malaney, P, (2003). Micro-economic Approaches to evaluating the Burden of Malaria. CID working Paper No. 99. Harvard.

xv. Mills, A, (1998). Operational research on the Economics of insecticides treated Mosquito nets: Lesson of Experience. Annals of Tropical Medicine and Parasitology 92 (4):18 - 28

xvi. Multilateral Imitative of Malaria [MIM], (2001). The Intolerable burden of Malaria. A new Look at Numbers. The American Journal of Tropical Medicine and Hygiene, 56(4):282-287.

xvii. Narain, J.P, (2008). Malaria in the south-east region: Myth and the reality. Indian Journal of Medical Research, 128: 1-3.

xviii. National Bureau of Statistics (NBS), (2016). Social Statistics Report 2016. Federal Government of Nigeria, Abuja. https://www.nigerianstat.gov.ng.

xix. Ogebe, F.O., Umeh, J.C \& Abu, G.A, (2017). Impact of Onchocerciasis (River-blindness) on Agricultural Productivity of North-central Nigeria. Journal of Agricultural Economics, Extension and Science. (JAEES) Vol. 3(2), Pp. 118-129.

$x x$. Ochi, J.E., Haruna, U., Mustapha, S., Samson, D., Ahmed, U \& Zailani, O., (2007). Beneficiary assessment/Impact evaluation of the Second National Fadama Development Project in Bauchi State, Vols. I\&II, 180pp.

xxi. Russell, S, (2004). The Economic burden of illness for households in developing countries: A review of studies focusing on Malaria, Tuberculosis, Onchocerciasis and Human Immunodeficiency virus (Acquired Immunedeficiency Syndrome). American Journal of Tropical Medicine and Hygiene 71 (suppl. 2): 147 - 155.

xxii. World Health Organization [WHO], (1999). The World Health Report: Making a Difference. Geneva Switzerland: World Health Organization. 59p

xxiii. World Health Organization [WHO], (2010). World Malaria Report 2012. Geneva. 